\title{
UPAYA MENINGKATKAN PRESTASI BELAJAR IPA DENGAN METODE COOPERATIVE LEARNING JIGSAW
}

\author{
SOFIANITA \\ MTs Negeri 1 Kudus, Jawa Tengah \\ email : sofianitag@gmail.com
}

\begin{abstract}
ABSTRAK
Penelitian ini bertujuan untuk mengetahui pengaruh metode Cooperatif Learning Jigsaw untuk meningkatkan aktivitas guru dan prestasi belajar IPA siswa kelas VIII MTs Negeri 1 Kudus Tahun Pelajaran 2015/2016 (subyek penelitian siswa kelas VIII D berjumlah 42 siswa). Metode yang digunakan adalah metode Penelitian Tindakan Kelas yang terdiri dari tiga siklus dengan teknik analisa data berupa analisis perbandingan peristiwa yang timbul dari tiap siklus berupa nilai dan peningkatannya. Dari keseluruhan putaran/siklus yang telah dilakukan, dapat disimpulkan bahwa penerapan metode pembelajaran Cooperative Learning Jigsaw dapat dijelaskan bahwa: 1) Aktivitas siswa pada siklus I sampai III mengalami peningkatan dari $48,30 \%$ menjadi $83,45 \%, 2)$ Aktivitas guru pada siklus I hingga III juga mengalami peningkatan dari $57,75 \%$ menjadi $89,50 \%$ dan, 3) Prestasi belajar IPA pada kemampuan awal nilai rata-rata kelas 60,00 pada siklus I sampai III menjadi 73,10. Penerapan metode pembelajaran tersebut cukup efektif di mana jumlah siswa mendapat nilai 65 ke atas mencapai 85,71\% sehingga diasumsikan bahwa sebagian besar siswa telah menuntaskan belajar IPA, dan tinggal 6 siswa (14,29\%) yang belum menuntaskan belajar IPA yang memiliki nilai rata-rata 60. Metode pembelajaran tersebut terbukti sesuai dan baik dalam upaya meingkatakan aktifitas belajar siswa di Kelas VIII MTs Negeri 1 Kudus Kabupaten Kudus.
\end{abstract}

Kata Kunci: Model Cooperative Learning Jigsaw, Aktifitas guru, Prestasi belajar IPA

\begin{abstract}
This study aims to determine the effect of the Cooperative Learning Jigsaw method to increase teacher activity and science learning achievement for VIII grade students of MTs Negeri 1 Kudus for the academic year 2015/2016 (the research subjects of class VIII D students are 42 students). The method used is the Classroom Action Research method which consists of three cycles with data analysis techniques in the form of comparative analysis of events arising from each cycle in the form of value and its increase. From the entire cycle that has been done, it can be concluded that the application of the Jigsaw Cooperative Learning method can be explained that: 1) Student activity in cycles I to III has increased from $48.30 \%$ to $83.45 \%, 2$ ) Teacher activity in the cycle I to III also experienced an increase from $57.75 \%$ to $89.50 \%$ and, 3) Science learning achievement at the initial ability, the class average value of 60.00 in cycles I to III became 73.10. The application of this learning method is quite effective where the number of students who score 65 and above reaches $85.71 \%$, so it is assumed that most of the students have completed learning science, and only 6 students $(14.29 \%)$ have not finished learning science who have an average score. -
\end{abstract}


average 60 . The learning method proved to be appropriate and good in the effort to increase student learning activities in Class VIII MTs Negeri 1 Kudus, Kudus Regency.

Keywords: Jigsaw Cooperative Learning Model, Teacher activity, Science learning achievement

\section{PENDAHULUAN}

Proses pembelajaran yang berlangsung di sekolah meliputi semua aktivitas yang memberikan materi pelajaran kepada siswa agar siswa mempunyai kecakapan dan pengetahuan memadai yang dapat memberikan manfaat dalam kehidupannya. Dalam proses belajar mengajar IPA selain melibatkan pendidik dan siswa secara langsung, juga diperlukan pendukung yang lain yaitu: alat pelajaran yang memadai, penggunaan metode yang tepat, serta situasi dan kondisi lingkungan yang menunjang.

Menurut Undang-Undang Sistem Pendidikan Nasional tahun 2003 nomor 20 diterangkan bahwa Pendidikan adalah usaha sadar dan terencana untuk mewujudkan suasana belajar dan proses pembelajaran agar peserta didik secara aktif mengembangkan potensi dirinya untuk memiliki kekuatan spiritual keagamaan, pengendalian diri, kepribadian, kecerdasan, akhlak mulia, serta keterampilan yang diperlukan dirinya, masyarakat, bangsa, dan negara. Untuk mewujudkan tujuan pendidikan tersebut, maka guru mempunyai peranan dalam menentukan keberhasilan peserta didik. Guru memiliki peranan dalam menyampaikan pesan dan isi kurikulum kepada peserta didiknya, serta bagaimana pula seorang guru memberikan layanan belajar yang efektif kepada murid-muridnya dalam mengatasi masalah-masalah yang sering muncul dalam pelaksanaan pendidikannya, khususnya masalah prestasi belajar.

Faktor yang menghambat dalam proses pembelajaran adalah siswa kurang memperhatikan bahan ajar, guru yang kurang mampu dalam melaksanakan proses pembelajaran sehingga membosankan, tempat dan waktunya tidak tepat, sarana prasarana pengajaran tidak lengkap yang menyebabkan siswa tidak tertarik terhadap materi pelajaran yang diajarkan. Dengan dasar ini maka perlu adanya suatu perubahan dengan mengambil langkah mengubah sistem yang digunakan dalam pembelajaran. Sudjana (2002) menjelaskan bahwa "Terdapat dua faktor utama yang mempengaruhi belajar yaitu dari dalam dan dari luar" Kemampuan, minat, motivasi, kreatifitas, perhatian dan kebebasan adalah faktor dari dalam adapun faktor dari luar meliputi lingkungan belajar, sarana prasarana belajar, kurikulum, dan kebijakan terutama yang mempengaruhi kualitas pembelajaran. Diantara faktor di atas ada faktor lain yaitu faktor psikologis yang menyebabkan siswa dapat berhasil atau gagal dalam mencapai tujuan secara optimal. Metode Pembelajaran berguna membantu siswa mencapai keberhasilan secara maksimal. Metode merupakan salah satu alat yang dapat mempengaruhi hasil belajar termasuk hasil belajar IPA, sehingga metode ini dapat dikategorikan ke dalam faktor eksternal. 
Penerapan model pembelajaran dengan pendekatan Cooperative Learning dapat meningkatkan self-esteem, kemampuan interpersonal dan menerima kesenjangan akademik diantara siswa. Disamping itu pendekatan Cooperative Learning dapat mendorong siswa memiliki motivasi, keberanian, dan memiliki toleransi terhadap berbagai budaya di dalam kelas yang heterogen. Model pembelajaran Cooperative Learning banyak macamnya, salah satunya adalah Jigsaw. Metode pembelajaran Jigsaw dapat digunakan dalam proses pengajaran melalui beberapa cara diantaranya teknik membaca, menulis, hingga berbicara (Lie, 2003).

Metode pembelajaran Jigsaw menurut Slavin (2007) dilakukan dengan cara menempatkan beberapa siswa dalam suatu tim dengan anggota rata-rata sebanyak 6 orang. Setelah ditempatkan dalam sebuah tim, langkah selanjutnya adalah masingmasing tim diberikan beberapa persoalan yang harus diselesaikan secara bersama dalam jangka waktu tertentu. Metode Jigsaw menurutnya merupakan metode yang paling sesuai digunakan untuk beberapa subyek pelajaran diantaranya ilmu pengetahuan ilmiah hingga ilmu sosial. Sehubungan dengan itu model pembelajaran memegang peranan penting untuk meningkatkan kualitas proses belajar mengajar. Pelajaran yang disampaikan dengan model pembelajaran akan menghasilkan tanggapan yang jelas. Semakin baik tanggapan seseorang tentang objek, orang, peristiwa atau hubungan, semakin baik hal tersebut dimengerti dan diingat. Siswa Madrasah Tsanawiyah pola berpikir kongkritnya masih relatif besar. Dalam penyajian mata pelajaran IPA dituntut pengamatan secara jelas. Oleh karena itu, untuk mengurangi verbalisme, penyampaiannya memerlukan model pembelajaran sesuai. Upaya meningkatkan prestasi belajar mata pelajaran IPA di sekolah khususnya di Madrasah Tsanawiyah dapat berhasil dengan baik dan maksimal bila didukung oleh metode belajar yang efektif dari guru. Metode pembelajaran Cooperative Learning Jigsaw termasuk faktor yang mempengaruhi prestasi belajar yang berasal dari luar diri siswa, karena pembelajaran Cooperative Learning Jigsaw memiliki kelebihan dimana para siswa bekerja sama dalam kelompok kecil untuk saling membantu satu sama lain dalam belajar. Guru juga diharapkan mempunyai teknik atau cara tertentu dalam penerapan model pembelajaran antara lain proses pembelajaran harus kooperatif, inkuiri, dan konsektual (Astuti dan Supriyadi, 2004).

Pembelajaran kooperatif melibatkan proses pembelajaran secara kooperatif antar siswa dalam rangka mencapai tujuan belajar. Demikian pula, dalam belajar IPA, siswa melakukan interaksi antar mereka dalam belajar berbagai aspek. Mereka dapat saling belajar berbagai aspek yang terdapat dalam IPA dari satu kelompok ke kelompok yang lainnya. Oleh sebab itu model pembelajaran kooperatif dipandang layak dan sesuai untuk proses pembelajaran IPA. Berdasarkan uraian di atas maka perlu adanya upaya meningkatkan prestasi belajar IPA dengan metode Cooperative Learning Jigsaw di Madrasah Tsanawiyah Negeri 1 Kudus Tahun Pelajaran 2015/2016. 
METODE PENELITIAN

Arikunto (2003) menyatakan bahwa metode penelitian merupakan suatu cara yang digunakan oleh peneliti untuk mengumpulkan data penelitian dan menyajikannya dengan baik. Metode yang digunakan dalam penelitian ini adalah PTK (Penelitian Tindakan Kelas). Penelitian ini menggunakan 3 siklus dimana setiap siklus memiliki indikator yang hendak dicapai dan hasilnya digunakan untuk refleksi langkah-langkah selanjutnya. Tahapan pada setiap siklus terdiri dari tahap perencanaan, pelaksanaan tindakan, pengamatan dan refleksi. Populasi penelitian ini diambil dengan menggunakan seluruh siswa kelas VIII yang terletak di MTs Negeri 1 Kudus Tahun Pelajaran 2015/2016. Subjek penelitian ini yaitu siswa kelas VIII-D MTs Negeri 1 Kudus Tahun Pelajaran 2015/2016 yang berjumlah 42 siswa yaitu 22 siswa putra dan 20 siswa putri.

Data yang dianalisa adalah data pengamatan aktivitas siswa, pengamatan aktivitas guru, dan prestasi belajar siswa yang diperoleh selama berlangsungnya penetian tindakan kelas, yaitu berupa nilai dari masing-masing pengamatan setelah diberikan tes pada akhir siklus. Teknis analisis data yang digunakan adalah perbandingan, artinya kejadian yang timbul dibandingkan kemudian disdeskripsikan ke dalam suatu bentuk data penilaian yang berupa kata-kata yang dapat menggambarkan keadaan secara sistimatis. Kejadian-kejadian yang terekam akan ditabulasikan secara nominal kemudian ditentukan prosentasenya. Dari prosentase itu akan dideskripsikan ke arah kecenderungan tindakan guru dan reaksi serta hasil belajar siswa dalam bentuk grafik. Penelitian Tindakan Kelas ini terdiri dari 3 siklus, tiap siklus dilaksanakan dengan indikator yang ingin dicapai dan hasil tiap siklus digunakan untuk merefleksi langkah-langkah yang hendak dilakukan berikutnya. Jadi dalam penelitian ini masing-masing siklus terdiri dari: (1). Planning/perencanaan, (2). Acting/ Pelaksanaan, (3). Observing/pengamatan, dan (4) Reflecting/refleksi

\section{HASIL DAN PEMBAHASAN}

Menurut Rusyan, dkk. (2002: 209) untuk mengukur hasil belajar perlu dievaluasi sebagai tindakan atau proses untuk menentukan nilai segala sesuatu yang ada hubungannya dengan pendidikan.

Evaluasi berarti penentuan sampai seberapa jauh sesuatu berharga, bermutu atau bernilai. Evaluasi terhadap hasil belajar yang dicapai oleh siswa dan terhadap proses belajar mengajar mengandung penilaian terhadap hasil belajar atau proses belajar itu, sampai seberapa jauh keduanya dapat dinilai baik (Winkel ,2003) 
a. Penilaian Aktivitas Belajar Siklus I

Dari penilaian siklus I aktivitas belajar siswa dengan penerapan metode pembelajaran Cooperative Learning Jigsaw diperoleh hasil sebagai berikut:

Tabel 1. Aktivitas Siswa Dalam Pembelajaran IPA Siklus I.

\begin{tabular}{|c|c|c|c|}
\hline No. & Aktivitas & Jumlah & Persentase \\
\hline 1 & Mendengarkan penjelasan guru. & 28 & $66,67 \%$ \\
\hline 2 & Membaca materi. & 22 & $52,38 \%$ \\
\hline 3 & Mencatat materi penting. & 18 & $42,86 \%$ \\
\hline 4 & Mengerjakan LKS & 30 & $71,43 \%$ \\
\hline 5 & Berdiskusi dengan guru & 20 & $47,62 \%$ \\
\hline 6 & Bertanya pada teman/guru & 14 & $33,33 \%$ \\
\hline \multirow[t]{2}{*}{7} & Menjadi pembicara kelompok & 10 & $23,81 \%$ \\
\hline & Jumlah / Rata-rata & 142 & $48,30 \%$ \\
\hline
\end{tabular}

Dari hasil pengamatan pada siklus I, diperoleh dari lembar pengamatan aktivitas belajar yang mencakup: 1) mendengarkan penjelasan guru $(66,67 \%) ; 2)$ membaca materi $(52,38 \%) ; 3)$ mencatat materi penting $(42,86 \%) ; 4)$ mengerjakan LKS (71,43\%); 5) mengerjakan LKS (71,43\%); 6) berdiskusi dengan guru $(33,33 \%)$; dan 7) menjadi pembicara kelompok $(23,81 \%)$.

Berdasarkan hasil pengamatan tersebut di atas, dapat disimpulkan bahwa aktivitas siswa dalam pembelajaran IPA dengan menerapkan metode Cooperative Learning Jigsaw sebagian besar siswa belum memiliki aktivitas yang diharapkan, karena rata-rata aktivitas belajar siswa masih rendah yaitu 48,30\%, sehingga guru memotivasi belajar siswa dengan menjelaskan keuntungan dan kelebihan metode Cooperative Learning Jigsaw, dengan penekanan tersebut diharapkan pada siklus berikutnya ada peningkatan yang signifikan terhadap aktivitas belajar siswa.

b. Penilaian Aktivitas Belajar Siklus II

Dari penilaian siklus II aktivitas belajar siswa dengan penerapan metode pembelajaran Cooperative Learning Jigsaw diperoleh hasil sebagai berikut:

Tabel 2. Aktivitas Siswa Dalam Pembelajaran IPA Siklus II.

\begin{tabular}{|c|l|c|c|}
\hline No. & \multicolumn{1}{|c|}{ Aktivitas } & Jumlah & Persentase \\
\hline 1 & Mendengarkan penjelasan guru. & 34 & $80,95 \%$ \\
2 & Membaca materi. & 30 & $71,43 \%$ \\
3 & Mencatat materi penting. & 26 & $61,90 \%$ \\
4 & Mengerjakan LKS & 36 & $85,71 \%$ \\
5 & Berdiskusi dengan guru & 32 & $76,19 \%$ \\
6 & Bertanya pada teman/guru & 24 & $57,14 \%$ \\
7 & Menjadi pembicara kelompok & 20 & $47,62 \%$ \\
\hline & Jumlah / Rata-rata & 202 & $68,71 \%$ \\
\hline
\end{tabular}

Dari hasil pengamatan pada siklus II, diperoleh dari lembar pengamatan aktivitas belajar yang mencakup: 1) mendengarkan penjelasan guru $(80,95 \%) ; 2)$ membaca materi $(71,43 \%) ; 3)$ mencatat materi penting $(61,90 \%) ; 4)$ mengerjakan 
LKS $(85,71 \%)$; 5) berdiskusi dnegan guru $(76,19 \%)$; 6) bertanya pada teman/guru $(57,14 \%)$; dan 7) menjadi pembicara kelompok $(47,62 \%)$.

Berdasarkan hasil pengamatan tersebut di atas, dapat disimpulkan bahwa aktivitas siswa dalam pembelajaran IPA dengan menerapkan metode Cooperative Learning Jigsaw sebagian besar siswa telah memiliki aktivitas yang meningkat bila dibandingkan dengan aktivitas pada siklus I rata-rata aktivitas belajar siswa sebesar 48,30 mengalami kenaikan menjadi sebesar $68,71 \%$, guru terus memotivasi belajar siswa untuk hasil tindakan siklus berikutnya dengan menjelaskan keuntungan dan kelebihan metode Cooperative Learning Jigsaw, dengan penekanan tersebut diharapkan akan mengalami peningkatan yang signifikan terhadap aktivitas belajar siswa.

c. Penilaian Aktivitas Belajar Siklus III

Dari penilaian siklus III aktivitas belajar siswa dengan penerapan metode pembelajaran Cooperative Learning Jigsaw diperoleh hasil sebagai berikut:

Tabel 3. Aktivitas Siswa Dalam Pembelajaran IPA Siklus III.

\begin{tabular}{|c|l|c|c|}
\hline No. & \multicolumn{1}{|c|}{ Aktivitas } & Jumlah & Persentase \\
\hline 1 & Mendengarkan penjelasan guru. & 42 & $100,00 \%$ \\
2 & Membaca materi. & 36 & $85,71 \%$ \\
3 & Mencatat materi penting. & 32 & $76,19 \%$ \\
4 & Mengerjakan LKS & 42 & $100,00 \%$ \\
5 & Berdiskusi dengan guru & 38 & $90,48 \%$ \\
6 & Bertanya pada teman/guru & 30 & $71,43 \%$ \\
7 & Menjadi pembicara kelompok & 28 & $66,67 \%$ \\
\hline & Jumlah / Rata-rata & 248 & $84,35 \%$ \\
\hline
\end{tabular}

Dari hasil pengamatan pada siklus III, diperoleh dari lembar pengamatan aktivitas belajar yang mencakup: 1) mendengarkan penjelasan guru (100,00\%);2) membaca materi $(85,71 \%)$; 3) mencatat materi penting $(76,19 \%)$; 4) mengerjakan LKS (100,00\%); 5) berdiskusi dnegan guru $(90,48 \%) ; 6$ ) bertanya pada teman/guru (71,34\%); dan 7) menjadi pembicara kelompok $(66,67 \%)$.

Berdasarkan hasil prosentase di atas, dapat disimpulkan bahwa aktivitas belajar siswa dengan menerapkan metode Cooperative Learning Jigsaw sebagian besar siswa telah memiliki aktivitas belajar yang menggembirakan bila dibandingkan dengan aktivitas pada siklus II rata-rata aktivitas belajar siswa sebesar 68,71 mengalami kenaikan menjadi sebesar $84,35 \%$, yang dapat diasumsikan bahwa aktivitas belajar dengan penerapan metode pembelajaran Cooperative Learning Jigsaw siswa merasa senang dan dapat memotivasi siswa untuk giat belajar sehingga prestasi belajarnya akan terus meningkat. 
Tabel 4. Aktivitas Belajar Siswa Setiap Siklus Dengan Menerapkan Metode Pembelajaran Cooperative Learning Jigsaw.

\begin{tabular}{|l|c|c|c|c|c|c|}
\hline \multirow{2}{*}{\multicolumn{1}{|c|}{ Aktivitas }} & \multicolumn{2}{c|}{ Siklus I } & \multicolumn{2}{c|}{ Siklus II } & \multicolumn{2}{c|}{ Siklus III } \\
\cline { 2 - 7 } & Jml & $\mathbf{\%}$ & Jml & \% & Jml & \% \\
\hline Mendengarkan penjelasan guru. & 28 & 66,67 & 34 & 80,95 & 42 & 100,00 \\
Membaca materi. & 22 & 52,38 & 30 & 71,43 & 36 & 85,71 \\
Mencatat materi penting. & 18 & 42,86 & 26 & 61,90 & 32 & 76,19 \\
Mengerjakan LKS & 30 & 71,43 & 36 & 85,71 & 42 & 100,00 \\
Berdiskusi dengan guru & 20 & 47,62 & 32 & 76,19 & 38 & 90,48 \\
Bertanya pada teman/guru & 14 & 33,33 & 24 & 57,14 & 30 & 71,43 \\
Menjadi pembicara kelompok & 10 & 23,81 & 20 & 47,62 & 28 & 66,67 \\
\hline \multicolumn{1}{|c|}{ Jumlah / Rata-rata } & 142 & 48,30 & 202 & 68,71 & 248 & 84,35 \\
\hline
\end{tabular}

Dari hasil nilai rata-rata dari setiap siklus dapat dibuat tabel perbandingan sebagai berikut:

Tabel 5. Peningkatan Aktivitas Belajar Siswa Setiap Siklus

\begin{tabular}{|l|c|c|}
\hline \multicolumn{1}{|c|}{ S i k I u S } & Nilai Rata-rata & Peningkatan \\
\hline Siklus I & $48,30 \%$ & - \\
\hline Siklus II & $68,71 \%$ & $20,41 \%$ \\
\hline Siklus III & $84,35 \%$ & $12,24 \%$ \\
\hline
\end{tabular}

Dari peningkatan aktivitas belajar siswa tersebut dapat digambarkan dalam bentuk grafik sebagai berikut:

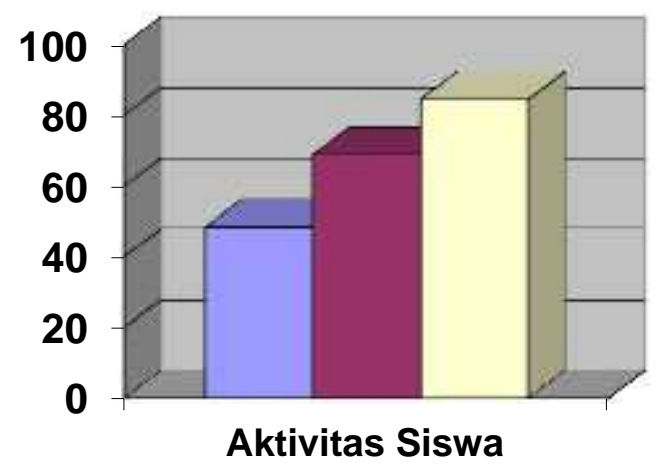

\section{口SikJus I 口Siklus II 口SikJus III}

Gambar 1. Grafik Peningkatan Aktivitas Belajar IPA Setiap Siklus

Dari grafik di atas menunjukkan kenaikan aktivitas belajar siswa dengan menerapkan metode cooperative learning jigsaw dari siklus ke siklus. Semakin siswa menyenangi penerapan metode cooperative learning jigsaw, aktivitas bealjar siswa akan semakin meningkat sehingga ketuntasan aktivitas belajar dapat tercapai.

\section{Penilaian Aktivitas Guru}

Setelah melaksanakan dan menyelesaikan tindakan pada setiap siklus dan diadakan penilaian akhir pada setiap siklus, kemudian dilakukan perbandingan peningkatan aktivitas guru setelah menerapkan pembelajaran 
dengan metode Cooperative Learning Jigsaw dan sekaligus mengadakan refleksi.

- $\quad$ Penilaian Aktivitas Guru Siklus I

Dari penilaian siklus I aktivitas guru mengajar yang meliputi persiapan, kegiatan belajar mengajar, dan penutup dengan menerapkan metode pembelajaran Cooperative Learning Jigsaw diperoleh hasil sebagai berikut:

Tabel 6. Aktivitas Guru Dalam Pembelajaran IPA Siklus I.

\begin{tabular}{|c|l|c|r|}
\hline No. & \multicolumn{1}{|c|}{ Aspek yang Dinilai } & Jumlah & Persentase \\
\hline 1 & Melaksanakan persiapan & 14 & $56,00 \%$ \\
2 & Melaksanakan pendahuluan & 6 & $60,00 \%$ \\
3 & Melaksanakan metode Jigsaw & 22 & $55,00 \%$ \\
4 & Melaksanakan penutup & 6 & $60,00 \%$ \\
\hline & Jumlah / Rata-rata & 48 & $57,75 \%$ \\
\hline
\end{tabular}

Dari hasil pengamatan pada siklus I, diperoleh dari lembar pengamatan aktivitas guru dalam pembelajaran IPA yang mencakup: 1) melaksanakan persiapan pembelajaran yang meliputi 4 indikator memperoleh skor $14(56,00 \%)$; 2) melaksanakan pendahuluan yang meliputi dua indikator memperoleh skor $6(60,00 \%) ; 3)$ melaksanakan metode Jigsaw yang meliputi 8 indikator memperoleh skor $22(55,00 \%)$; 4) melaksanakan penutupan pembelajaran yang meliputi 2 indikator memperoleh skor $6(60,00 \%)$.

Dari hasil pengamatan tersebut di atas, dapat disimpulkan bahwa aktivitas guru dalam pembelajaran IPA dengan menerapkan metode Cooperative Learning Jigsaw belum menunjukkan aktivitas yang diharapkan, karena rata-rata aktivitas mengajar guru masih rendah yaitu $57,75 \%$, sehingga diperlukan kreativitas guru untuk lebih mendalami metode Cooperative Learning Jigsaw, dengan penekanan tersebut diharapkan pada siklus berikutnya ada peningkatan yang signifikan terhadap aktivitas guru dalam pembelajaran.

\section{- $\quad$ Penilaian Aktivitas Guru Siklus II}

Dari penilaian siklus II aktivitas guru mengajar yang meliputi persiapan, kegiatan belajar mengajar, dan penutup dengan menerapkan metode pembelajaran Cooperative Learning Jigsaw diperoleh hasil sebagai berikut:

Tabel 7. Aktivitas Guru Dalam Pembelajaran IPA Siklus II.

\begin{tabular}{|c|l|c|r|}
\hline No. & Aspek yang Dinilai & Jumlah & Persentase \\
\hline 1 & Melaksanakan persiapan & 18 & $72,00 \%$ \\
2 & Melaksanakan pendahuluan & 8 & $80,00 \%$ \\
3 & Melaksanakan metode Jigsaw & 30 & $75,00 \%$ \\
4 & Melaksanakan penutup & 8 & $80,00 \%$ \\
\hline & Jumlah / Rata-rata & 64 & $76,75 \%$ \\
\hline
\end{tabular}

Dari hasil pengamatan pada siklus II, diperoleh dari lembar pengamatan aktivitas guru dalam pembelajaran IPA yang mencakup: 1) melaksanakan persiapan pembelajaran yang meliputi 5 indikator memperoleh skor $18(72,00 \%)$; 2) melaksanakan pendahuluan yang meliputi 2 indikator 
memperoleh skor $8(80,00 \%)$; 3) melaksanakan metode Jigsaw yang meliputi 8 indikator memperoleh skor $30(75,00 \%)$; 4) melaksanakan penutupan pembelajaran yang meliputi 2 indikator memperoleh skor $8(80,00 \%)$.

Dari hasil pengamatan tersebut di atas, dapat disimpulkan bahwa aktivitas guru dalam pembelajaran IPA dengan menerapkan metode Cooperative Learning Jigsaw telah menunjukkan aktivitas yang menggembirakan walaupun belum mencapai ketuntasan aktivitas mengajar, rata-rata aktivitas mengajar guru meningkat menjadi $76,75 \%$, guru perlu meningkatkan untuk lebih mendalami metode Cooperative Learning Jigsaw, dengan motivasi tersebut diharapkan pada siklus berikutnya ada peningkatan yang signifikan terhadap aktivitas guru dalam pembelajaran.

- Penilaian Aktivitas Guru Siklus III

Dari penilaian siklus III aktivitas guru mengajar yang meliputi persiapan, kegiatan belajar mengajar, dan penutup dengan menerapkan metode pembelajaran Cooperative Learning Jigsaw diperoleh hasil sebagai berikut:

Tabel 8. Aktivitas Guru Dalam Pembelajaran IPA Siklus III.

\begin{tabular}{|c|l|c|r|}
\hline No. & Aspek yang Dinilai & Jumlah & Persentase \\
\hline 1 & Melaksanakan persiapan & 22 & $88,00 \%$ \\
2 & Melaksanakan pendahuluan & 9 & $90,00 \%$ \\
3 & Melaksanakan metode Jigsaw & 36 & $90,00 \%$ \\
4 & Melaksanakan penutup & 9 & $90,00 \%$ \\
\hline & Jumlah / Rata-rata & 76 & $89,50 \%$ \\
\hline
\end{tabular}

Dari hasil pengamatan pada siklus III, diperoleh dari lembar pengamatan aktivitas guru dalam pembelajaran IPA yang mencakup: 1) melaksanakan persiapan pembelajaran yang meliputi 5 indikator memperoleh skor $22(88,00 \%)$; 2) melaksanakan pendahuluan yang meliputi 2 indikator memperoleh skor 9 (90,00\%); 3) melaksanakan metode Jigsaw yang meliputi 8 indikator memperoleh skor $36(90,00 \%)$; 4) melaksanakan penutupan pembelajaran yang meliputi 2 indikator memperoleh skor $9(90,00 \%)$.

Dari hasil pengamatan tersebut di atas, dapat disimpulkan bahwa aktivitas guru dalam pembelajaran IPA dengan menerapkan metode Cooperative Learning Jigsaw telah menunjukkan aktivitas yang menggembirakan, karena rata-rata aktivitas mengajar guru meningkat menjadi $89,50 \%$ yang berarti telah menuntaskan aktivitas mengajar yang ditetapkan yaitu $80 \%$, dengan peningkatan tersebut diharapkan guru akan semakin menyukai metode Cooperative Learning Jigsaw, ketertarikan guru terhadap metode tersebut diharapkan akan menjadikan guru rajin mengajar dan aktivitas belajar siswa juga meningkat sehingga prestasi IPA dapat ditingkatkan untuk menuntaskan belajar IPA. 
Tabel 9. Aktivitas Guru Dalam Pembelajaran IPA Setiap Siklus Dengan Menerapkan Metode Pembelajaran Cooperative Learning Jigsaw.

\begin{tabular}{|l|c|c|c|c|c|c|}
\hline \multirow{2}{*}{ Aktivitas } & \multicolumn{2}{|c|}{ Siklus I } & \multicolumn{2}{c|}{ Siklus II } & \multicolumn{2}{c|}{ Siklus III } \\
\cline { 2 - 7 } & Jml & \% & Jml & \% & Jml & \% \\
\hline Persiapan & 14 & 56,00 & 18 & 72,00 & 22 & 88,00 \\
Pendahuluan & 6 & 60,00 & 8 & 80,00 & 9 & 90,00 \\
Melaksanakan Jigsaw & 22 & 55,00 & 30 & 75,00 & 36 & 90,00 \\
Penutup & 6 & 60,00 & 8 & 80,00 & 9 & 90,00 \\
\hline \multicolumn{1}{|c|}{ Jumlah / Rata-rata } & 48 & 57,75 & 64 & 76,75 & 76 & 89,50 \\
\hline
\end{tabular}

Dari hasil nilai rata-rata dari setiap siklus dapat dibuat tabel perbandingan sebagai berikut:

Tabel 10. Peningkatan Aktivitas Guru Dalam Pembelajaran Setiap Siklus

\begin{tabular}{|l|c|c|}
\hline \multicolumn{1}{|c|}{ S i k I u S } & Nilai Rata-rata & Peningkatan \\
\hline Siklus I & $57,75 \%$ & - \\
\hline Siklus II & $76,75 \%$ & $19,00 \%$ \\
\hline Siklus III & $89,50 \%$ & $12,75 \%$ \\
\hline
\end{tabular}

Dari peningkatan aktivitas belajar siswa tersebut dapat digambarkan dalam bentuk grafik sebagai berikut:

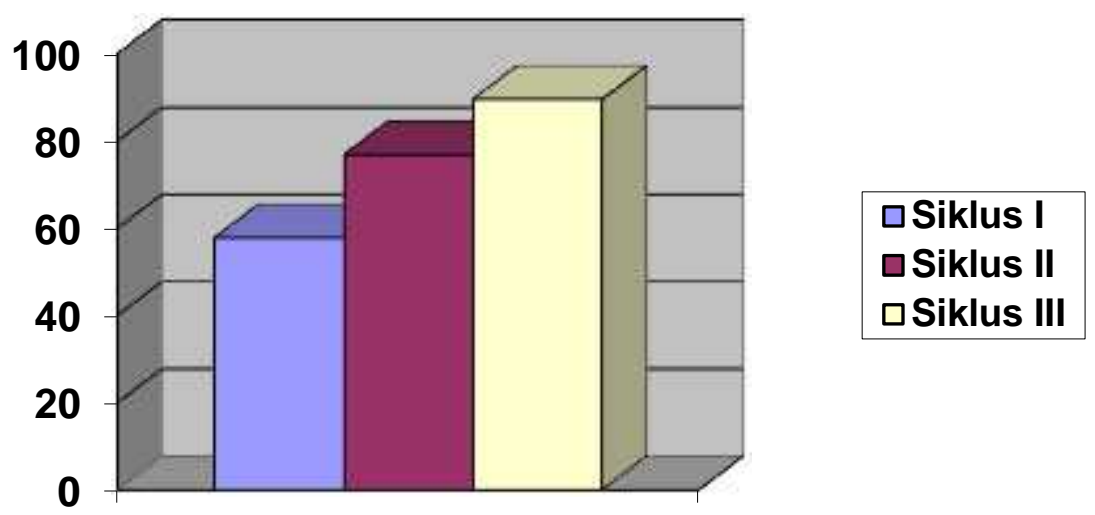

Aktivitas Guru

Gambar 2. Grafik Peningkatan Aktivitas Guru Setiap Siklus

Dari grafik di atas menunjukkan kenaikan aktivitas guru mengajar dengan menerapkan metode cooperative learning jigsaw dari siklus ke siklus. Semakin guru menyenangi penerapan metode cooperative learning jigsaw, aktivitas guru mengajar akan semakin meningkat sehingga ketuntasan aktivitas mengajar dapat tercapai.

\section{Penilaian Prestasi Belajar}

Setelah melaksanakan dan menyelesaikan tindakan pada setiap siklus dan diadakan penilaian akhir pada setiap siklus, kemudian dilakukan perbandingan peningkatan prestasi mata pelajaran IPA siswa setelah diterapkan pembelajaran dengan metode cooperative learning jigsaw dan sekaligus mengadakan refleksi. 
a. Penilaian Awal

Dari penilaian awal hasil belajar IPA siswa kelas VIII-D Madrasah Tsanawiyah Negeri 1 Kudus tahun pelajaran 2015/2016 sebelum dilakukan tindakan dengan penerapan metode pembelajaran Cooperative Learning Jigsaw diperoleh hasil sebagai berikut:

Tabel 11. Prestasi Belajar IPA Sebelum Menerapakan Pembelajaran Metode Cooperative Learning Jigsaw

\begin{tabular}{|c|c|c|c|}
\hline Nilai (N) & Jumlah $(\mathbf{F})$ & $\mathbf{N . F}$ & Prosentase \\
\hline 40 & 4 & 160 & $22,22 \%$ \\
50 & 10 & 500 & $37,04 \%$ \\
60 & 15 & 900 & $25,93 \%$ \\
70 & 8 & 560 & $11,11 \%$ \\
80 & 5 & 400 & $03,70 \%$ \\
\hline Jumlah & 42 & 2520 & $100 \%$ \\
\hline Rata-rata & \multicolumn{3}{|c}{$2520: 42=60,00$} \\
\hline
\end{tabular}

Dari tabel 11 dapat dilihat kondisi/keadaan awal sebelum diberi tindakan. Dalam hal ini berupa nilai prestasi IPA yang diperoleh dalam kegiatan belajar mengajar tanpa menerapkan metode pembelajaran cooperative learning jigsaw. Nilai diperoleh melalui tes yang dilaksanakan oleh guru mata pelajaran.

Pada keadaan awal dapat dilihat nilai rata-rata prestasi belajar siswa 60,00. Siswa yang mendapat nilai di bawah 65 sebanyak 29 siswa atau $69,05 \%$. Sedangkan siswa yang telah mencapai batas tuntas yaitu mendapat nilai 65 ke atas sebanyak 13 siswa atau 30,95\%. Dari prosentase tersebut berarti sebagian besar siswa belum mencapai hasil yang memuaskan dan paling banyak adalah siswa mendapat nilai 60 berjumlah 15 siswa $(25,93 \%)$.

b. Penilaian Siklus I

Dari penilaian siklus I hasil belajar IPA siswa kelas kelas VIII-D Madrasah Tsanawiyah Negeri 1 Kudus tahun pelajaran 2015/2016 setelah dilakukan tindakan dengan penerapan metode pembelajaran cooperative learning jigsaw diperoleh hasil sebagai berikut:

Tabel 12. Prestasi Belajar IPA Menerapakan Pembelajaran Metode Cooperative Learning Jigsaw Siklus I

\begin{tabular}{|c|c|c|c|}
\hline Nilai (N) & Jumlah (F) & N.F & Prosentase \\
\hline 40 & 1 & 40 & $22,22 \%$ \\
50 & 8 & 400 & $37,04 \%$ \\
60 & 16 & 960 & $25,93 \%$ \\
70 & 10 & 700 & $11,11 \%$ \\
80 & 7 & 560 & $03,70 \%$ \\
\hline Jumlah & 42 & 2660 & $100 \%$ \\
\hline Rata-rata & \multicolumn{3}{|c}{$2660: 42=63,33$} \\
\hline
\end{tabular}

Dari tabel 12 dapat dilihat hasil tindakan pada siklus I, prestasi IPA yang diperoleh dalam kegiatan belajar mengajar setelah menerapkan metode 
pembelajaran coperative learning jigsaw. Nilai diperoleh melalui tes yang dilaksanakan oleh guru mata pelajaran.

Pada siklus I nilai rata-rata kelas mengalami meningkatkan menjadi 63,33 jika dibandingkan dengan prestasi awal nilai rata-rata kelas 60,00, pada siklus I telah menunjukkan peningkatan walaupun presentase peningkatannya belum terlalu besar. Pada siklus I siswa yang mendapat nilai di bawah 65 sebanyak 25 siswa atau 59,52\%, siswa yang mendapat nilai 65 ke atas sebanyak 17 siswa atau 40,48\%. Dengan demikian ditinjau dari sudut ketuntasan belajar telah mengalami peningkatan dari 30,95\% menjadi $59,52 \%$ dan paling banyak adalah siswa mendapat nilai 60 berjumlah 16 siswa $(25,93 \%)$

c. Penilaian Siklus II

Dari penilaian siklus II hasil belajar IPA siswa kelas VIII-D Madrasah Tsanawiyah Negeri 1 Kudus tahun pelajaran 2015/2016 setelah dilakukan tindakan dengan penerapan metode pembelajaran cooperative larning jigsaw diperoleh hasil sebagai berikut:

Tabel 13. Prestasi Belajar Biologi Menerapakan Pembelajaran Metode Cooperative Learning Jigsaw Siklus II

\begin{tabular}{|c|c|c|c|}
\hline Nilai (N) & Jumlah (F) & N.F & Prosentase \\
\hline 50 & 4 & 200 & $09,24 \%$ \\
60 & 10 & 600 & $23,81 \%$ \\
70 & 18 & 1260 & $42,86 \%$ \\
80 & 8 & 640 & $19,05 \%$ \\
90 & 2 & 180 & $04,76 \%$ \\
\hline Jumlah & 42 & 2880 & $100 \%$ \\
\hline Rata-rata & \multicolumn{3}{|c}{$2880: 42=68,57$} \\
\hline
\end{tabular}

Dari tabel 13 dapat dilihat hasil tindakan pada siklus II, prestasi IPA yang diperoleh dalam kegiatan belajar mengajar setelah menerapkan metode pembelajaran cooperative learning jigsaw. Nilai diperoleh melalui tes yang dilaksanakan oleh guru mata pelajaran.

Pada siklus II nilai rata-rata kelas 68,57 jika dibandingkan dengan prestasi siklus I nilai rata-rata kelas 63,33, pada siklus II telah menunjukkan peningkatan. Pada siklus II siswa yang mendapat nilai di bawah 65 sebanyak 14 siswa atau $33,33 \%$, siswa yang mendapat nilai 65 ke atas sebanyak 28 siswa atau 66,67\%. Dengan demikian ditinjau dari sudut ketuntasan belajar telah mengalami peningkatan dari $59,52 \%$ menjadi $66,67 \%$ dan paling banyak adalah siswa mendapat nilai 70 berjumlah 18 siswa $(42,86 \%)$.

d. Penilaian Siklus III

Dari penilaian siklus III hasil belajar IPA siswa kelas VIII-D Madrasah Tsanawiyah Negeri 1 Kudus tahun pelajaran 2015/2016 setelah dilakukan tindakan dengan penerapan metode pembelajaran cooperative learning jigsaw diperoleh hasil sebagai berikut: 
Tabel 14. Prestasi Belajar IPA Menerapakan Metode Pembelajaran Cooperative Learning Jigsaw Siklus III

\begin{tabular}{|c|c|c|c|}
\hline Nilai (N) & Jumlah (F) & N.F & Prosentase \\
\hline 50 & - & - & - \\
60 & 6 & 360 & $23,81 \%$ \\
70 & 20 & 1400 & $42,86 \%$ \\
80 & 13 & 1040 & $19,05 \%$ \\
90 & 3 & 270 & $04,76 \%$ \\
\hline Jumlah & 42 & 3070 & $100 \%$ \\
\hline Rata-rata & \multicolumn{3}{|c}{$3070: 42=73,10$} \\
\hline
\end{tabular}

Dari tabel 14 dapat dilihat hasil tindakan pada siklus III, prestasi IPA yang diperoleh dalam kegiatan belajar mengajar setelah menerapkan metode pembelajaran cooperative learning jigsaw. Nilai diperoleh melalui tes yang dilaksanakan oleh guru mata pelajaran.

Pada siklus III nilai rata-rata kelas 73,10 jika dibandingkan dengan prestasi siklus II nilai rata-rata kelas 68,57, pada siklus III telah menunjukkan peningkatan yang berarti. Pada siklus III siswa yang mendapat nilai di bawah 65 tinggal 6 siswa atau 14,29\%, siswa yang mendapat nilai 65 ke atas sebanyak 36 siswa atau $85,71 \%$. Dengan demikian ditinjau dari sudut ketuntasan belajar telah mengalami peningkatan dari $66,67 \%$ menjadi $85,71 \%$ dan paling banyak adalah siswa mendapat nilai 70 berjumlah 20 siswa $(42,86 \%)$.

Tabel 15. Prestasi IPA Setiap Siklus Dengan Menerapkan Metode Pembelajaran Cooperative Learning Jigsaw.

\begin{tabular}{|c|c|c|c|c|c|c|}
\hline \multirow{2}{*}{ Nilai } & \multicolumn{2}{|c|}{ Siklus I } & \multicolumn{2}{c|}{ Siklus II } & \multicolumn{2}{c|}{ Siklus III } \\
\cline { 2 - 7 } & Jumlah & \% & Jumlah & \% & Jumlah & \% \\
\hline 40 & 1 & 22,22 & - & - & - & - \\
50 & 8 & 37,04 & 4 & 09,24 & - & - \\
60 & 16 & 25,93 & 10 & 23,81 & 6 & 23,81 \\
70 & 10 & 11,11 & 18 & 42,86 & 20 & 42,86 \\
80 & 7 & 03,70 & 8 & 19,05 & 13 & 19,05 \\
90 & - & - & 2 & 04,76 & 3 & 04,76 \\
\hline Jumlah & 42 & 100 & 42 & $100 \%$ & 27 & $100 \%$ \\
\hline Rata-rata & \multicolumn{2}{|c|}{$2660: 42=\mathbf{6 3 , 3 3}$} & \multicolumn{2}{|c|}{$2880: 42=\mathbf{6 8 , 5 7}$} & \multicolumn{2}{|c|}{$3070: 42=\mathbf{7 3 , 1 0}$} \\
\hline
\end{tabular}

Dari hasil nilai rata-rata dari setiap siklus dapat dibuat tabel perbandingan sebagai berikut:

Tabel 16. Peningkatan Nilai Rata-rata Prestasi IPA Setiap Siklus

\begin{tabular}{|l|c|c|}
\hline \multicolumn{1}{|c|}{ S i k I u s } & Nilai Rata-rata & Peningkatan \\
\hline Tes Awal & 60,00 & - \\
\hline Siklus I & 63,33 & 03,33 \\
\hline Siklus II & 68,57 & 05,24 \\
\hline Siklus III & 73,10 & 04,53 \\
\hline
\end{tabular}

Dari peningkatan prestasi belajar tersebut di atas dapat digambarkan dalam bentuk grafik sbb: 


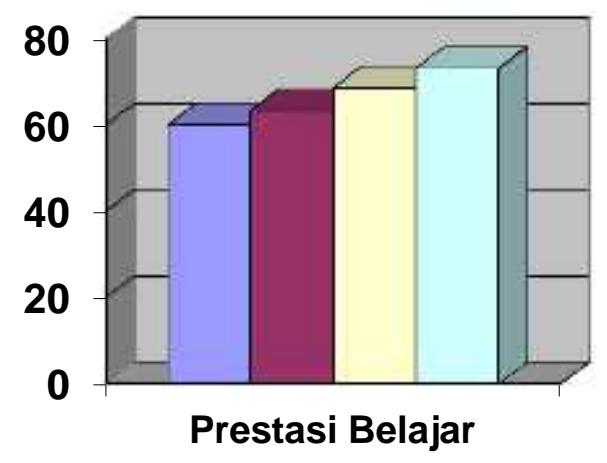

\section{口Tes Awal $\square$ SikJus I 口Siklus II $\square$ Siklus III}

Gambar 3. Grafik Peningkatan Prestasi Belajar IPA Setiap Siklus

Berdasarkan indikator kinerja yang telah ditetapkan bahwa prestasi belajar IPA siswa kelas VIII-D Madrasah Tsanawiyah Negeri 1 Kudus tahun pelajaran 2015/2016 tuntas ditentukan apabila $80 \%$ dari jumlah siswa mendapat nilai 65 ke atas. Dari hasil tindakan dengan penerapan metode pembelajaran cooperative learning jigsaw dapat diketahui jumlah siswa mendapat nilai 65 ke atas mencapai $85,71 \%$ sehingga diasumsikan bahwa sebagian besar siswa telah menuntaskan belajar IPA, dan tinggal 6 siswa (14,29\%) yang belum menuntaskan belajar IPA yang memiliki nilai rata-rata 60.

Penerapan metode Cooperative Learning Jigsaw dapat meningkatkan aktivitas guru, aktivitas belajar siswa, dan prestasi belajar IPA siswa. Metode pembelajaran Cooperative Learning Jigsaw termasuk faktor yang mempengaruhi prestasi belajar yang berasal dari luar diri siswa, karena pembelajaran Cooperative Learning Jigsaw memiliki kelebihan di mana para siswa bekerja sama dalam kelompok kecil untuk saling membantu satu sama lain dalam belajar. Pembelajaran kooperatif melibatkan proses pembelajaran secara kooperatif antar siswa dalam rangka mencapai tujuan belajar. Demikian pula, dalam belajar IPA, siswa melakukan interaksi antar mereka dalam belajar berbagai aspek. Mereka dapat saling belajar berbagai aspek yang terdapat dalam IPA dari satu kelompok ke kelompok yang lainnya. Oleh sebab itu model pembelajaran kooperatif dipandang layak dan sesuai untuk proses pembelajaran IPA.

Dari hasil penelitian tindakan kelas ini masih relevan bila dikaitkan teori mengenai kelebihan-kelebihan metode cooperative learning jigsaw karena metode ini memiliki dampak positif dalam meningkatkan self-esteem, kemampuan interpersonal dan menerima kesenjangan akademik di antara siswa. Di samping itu pendekatan Cooperative Learning dapat mendorong siswa memiliki motivasi, keberanian, dan memiliki toleransi terhadap berbagai budaya di dalam kelas yang heterogen. Model pendekatan Cooperative Learning efektif dalam meningkatkan kemampuan akademik, mengembangkan sikap-sikap siswa terhadap teman dan sekolah dan meningkatkan hubungan antara siswa dalam kelompok yang berbeda (kemampuan interpersonal).

\section{KESIMPULAN}

Kesimpulan dalam penelitian ini menunjukkan bahwa model pembelajaran dengan menggunakan metode Cooperative Learning Jigsaw dapat meningkatkan prestasi belajar pada siswa kelas VIII D MTs Negeri 1 Kudus. Peningkatan tersebut dilakukan dengan menggunakan berbagai materi pembelajaran IPA diantaranya materi 
Sistim Transportasi. Peningkatan hasil pembelajaran tersebut dapat diketahui dari nilai tes dari kondisi awal dengan nilai rata-rata 60,00, pada siklus I dengan nilai rata-rata 63,33 , ada peningkatan nilai 3,33, pada siklus II dengan nilai rata-rata 68,57, ada peningkatan nilai 5, 24 dan siklus III dengan nilai rata-rata 73,10, ada peningkatan nilai 4,53

Saran yang dapat disampaikan dalam penelitian ini dalam rangka meningkatkan prestasi belajar siswa yaitu: (1) Penggunaan métode Cooperative Learning Jigsaw agar dapat digunakan dalam rangka membuat siswa menjadi berperan aktif dalam proses belajar. (2) Terdapat beberapa aspek yang kita teliti yaitu aktivitas siswa, aktivitas guru dan prestasi belajar IPA. (3) Penelitian ini hanya terbatas pada mata pelajaran IPA yang terdiri dari materi Sistim Transportasi, sehingga dibutuhkan mata pelajaran lain agar dapat diketahui hasil yang berbeda.

\section{DAFTAR PUSTAKA}

Anita Lie. 2003. Cooperative Learning. "Mempraktikkan Cooperative Learning di Ruang-ruang Kelas". Jakarta: Grasindo.

Depdikbud. 2004. Kurikulum Pendidikan Dasar, Silabus. Jakarta: Dirjen Pendidikan Dasar dan Menengah.

Nana Sudjana, 2002. Cara Belajar Siswa Aktif Dalam Proses Belajar Mengajar. Bandung: Sinar Baru.

Puji Astuti dan Supriyadi. 2004. Peningkatan Prestasi Belajar Melalui Penerapan Model Pembelajaran Cooperative Learning. Karanganyar: APK.

Slavin R. 2007. Cooperative Learning. Second Edition. Allyn \& Bacon. A Kudusn \& Aschuster Company.

Suharsimi Arikunto. 2003. Prosedur Penelitian Suatu Praktek. Jakarta: Rineka Cipta.

Tabrani Rusyan, A., dkk. 2002. Pendekatan Dalam Proses Belajar Mengajar, Bandung: Remaja Karya.

Winkel, WS. 2003. Psikologi Pendidikan dan Evaluasi Belajar. Jakarta: Gramedia 